\title{
PROFILE OF PULMONARY ADENOCARCINOMA PATIENTS ON CORE BIOPSY EXAMINATION AT GENERAL CENTER HOSPITAL HAJI ADAM MALIK MEDAN 2017-2019
}

\author{
${ }^{1}$ Affan Akbar Talami, ${ }^{2}$ Delyuzar, ${ }^{3}$ Betty, ${ }^{4}$ Joko S Lukito, ${ }^{5}$ Soekimin \\ Email address: lindawatitalami@gmail.com \\ Department of Anatomic Pathology, Faculty of Medicine, Universitas Sumatera Utara \\ Medan, Indonesia
}

Abstract

\begin{abstract}
Background: Lung cancer is the most common cause of death in the world, mostly in high-income countries, at Friendship Hospital, adenocarcinoma is the most common type. Simple and rapid diagnosis is very important in reducing morbidity and mortality. One of the examination techniques used is a core biopsy. This study aims to determine the profile of lung adenocarcinoma patients using the core biopsy method at the HAM Hospital in 2017-2019. Methods: This study is descriptive with a cross sectional approach, with samples of all patients diagnosed with lung adenocarcinoma histopathologically through core biopsy, the number of samples is 108 samples with total sampling method. Results and discussion: the mean age is $57 \pm$ SD 11.71 years, the youngest is 18 years old and the oldest is 74 years old. 34 men (85\%), Batak 17 people (42.5\%) and Acehnese 1 person $(2.5 \%)$, farmer work 20 people (50\%) and civil servant job 4 people (10\%), smoking history 32 people (80\%), the most location in the peripheral area 24 cases $(60 \%)$, diameter $2 \mathrm{~cm} 12$ people $(30 \%)$ and $>2-3 \mathrm{~cm}$ 6 people (12\%), stage IVA 21 people ( 52.5\%) and IIIA in 1 person (2.5\%), solid variant adenocarcinoma 21 people $(52.5 \%)$ and enteric adenocarcinoma in 1 person $(2.5 \%)$. Conclusion: In this study, the oldest age was 74 years, male gender, Batak ethnicity, farmer occupation, smoking history, location in peripheral areas, diameter $2 \mathrm{~cm}$, stage IVA, solid adenocarcinoma was the most variant.
\end{abstract}

Keywords: adenocarcinoma; lung cancer; core biopsy.

\section{Introduction}

Lung cancer is the most common cause of death in the world. Based on WHO data, lung cancer ranks first in men followed by colorectal cancer, prostate cancer, liver cancer and nasopharyngeal cancer, while in women ranks 5th most after breast cancer. , uterine cervix, colorectal and ovaries. In Indonesia, currently the incidence of lung cancer in men also ranks highest. Cases of death in men caused by lung cancer were $21.8 \%$ while for women it was found to be $9.1 \%$ after breast cancer was $21.4 \%{ }^{1}$

The American Cancer Society estimates that every year the number of new cases and deaths in the United States continues to increase. In 2019 there were 1,762,450 cases with 606,880 deaths. In Southeast Asia in 2012 it was estimated that there were around 758 thousand new cases, of which lung cancer cases were the most common. Indonesia ranks third after China and India which reached 25,322 cases with a death rate of 22,522 cases. $^{2}$

Based on the classification of the International Association for the study of lung cancer (IASLC), bronchogenic adenocarcinoma currently has a prevalence of approximately $45 \%$, as much as 6.6\% with 11 cases). Melindawati's research in 2004-2008 at the HAM Hospital in Medan found as many as 378 cases of lung cancer. Men are more than women with a percentage of $86.1 \%$ and for ages $>60$ years, $40.8 \%$ of all cases are obtained. Based on ethnicity, the Batak tribe is the 
largest with a percentage of 58.2\%. Meanwhile, based on the type of histology, 99\% NSCLC was found consisting of 56.3\% adenocarcinoma, 2\% SCC and LCC, while 1\% SCLC was found. From Soeroso's research, $99 \%$ of NSCLC types were found, consisting of $56.8 \%$ adenocarcinoma, $37.12 \%$ SCC and $5.98 \%$ LCC. $^{3}$

Simple and rapid diagnostic enforcement is very important in reducing morbidity and mortality. To reduce mortality, it is necessary to immediately use an appropriate examination technique. ${ }^{1}$ One of the examination techniques performed is a CT-guided core biopsy. A core biopsy is often performed if a pulmonary nodule is found on X-ray and CT (computer tomography) scan. Core biopsy is generally a medical support measure to establish a diagnosis which is usually done by surgeons, pulmonologists, interventional cardiologists, or involving cells or tissues to be examined to determine the presence or absence of a disease. Core-biopsy is a technique similar to with Tranthoracic Needle Aspiration (TTNA) which uses a larger needle to obtain tissue for histopathological examination. This method is the right choice for establishing a diagnosis with a higher quality sample of material for analysis. ${ }^{4}$

\section{Method}

This study is a descriptive study that aims to determine the profile of patients with adenocarcinoma lung tumors through a core biopsy at the HAM Hospital Medan in 2017-2019 with a cross sectional approach. The sample in this study were all patients diagnosed histopathologically taken by a total sampling of 103 samples. Samples were obtained from medical records and slides of patients diagnosed histopathologically through a core biopsy as lung adenocarcinoma by consecutive sampling.

Working procedure: data on patients with lung adenocarcinoma type lung tumor on core biopsy examination at Haji Adam Malik General Hospital Medan were taken from medical records. The data obtained were checked for completeness, namely, age, gender, occupation, ethnicity, smoking status, location, size, stage, EGFR mutation status and subtype. Complete data were included in the study sample and incomplete data were excluded from the study sample. Slides and paraffin blocks were collected from data on patients with lung adenocarcinoma who met the inclusion criteria. Slides are checked for adequacy for re-evaluation. Adequate slides were included in the inclusion criteria, while inadequate slides i.e. damaged or missing were re-cut paraffin blocks. After reprocessing, slides that were adequate for re-evaluation were included in the inclusion criteria. Then re-evaluated by the researcher assisted by 2 research supervisors. Complete data and accompanied by adequate slides were used as research samples.

The data obtained by the researcher will then be processed and presented in tabular form. The research was conducted after obtaining approval from the Ethics Committee of the Faculty of Medicine, University of North Sumatra, Medan with No. 52/ KEP/ USU/ 2021.

\section{Results and Discussion}

The data obtained from lung adenocarcinoma patients from medical records at the HAM Hospital Medan were 108 samples, while the medical record data that met the inclusion and exclusion criteria were 40 samples, so that the medical record data taken for the study were 40 samples. In this study, clinical data including age, gender, ethnicity, occupation and smoking status were secondary data. The frequency distribution of the characteristics of lung adenocarcinoma patients in this study can be seen in table 4.1. 
Table 4.1. Frequency Distribution of Characteristics of Lung Adenocarcinoma Patients based on Clinical Picture Data

\begin{tabular}{|c|c|c|}
\hline Characteristics & $\begin{array}{c}\text { Amount } \\
\text { (n) }\end{array}$ & $\begin{array}{c}\text { Percentage } \\
(\%)\end{array}$ \\
\hline Age, mean $\pm \mathrm{SD}$, tahun & & \\
\hline \multicolumn{3}{|l|}{ Age group } \\
\hline $18-27$ years & 1 & 2,5 \\
\hline $28-37$ years & 2 & 5 \\
\hline $38-47$ years & 5 & 12,5 \\
\hline $48-57$ years & 9 & 22,5 \\
\hline $58-67$ years & 16 & 40 \\
\hline$>68$ years & 7 & 17,5 \\
\hline \multicolumn{3}{|l|}{ Gender } \\
\hline Male & 34 & 85 \\
\hline Female & 6 & 15 \\
\hline \multicolumn{3}{|l|}{ Ethnic group } \\
\hline Java & 10 & 25 \\
\hline Batak & 17 & 42,5 \\
\hline Malay & 2 & 5 \\
\hline Aceh & 1 & 2,5 \\
\hline Karo & 3 & 7,5 \\
\hline Mandailing & 7 & 17,5 \\
\hline \multicolumn{3}{|l|}{ Job } \\
\hline Civil servants & 4 & 10 \\
\hline Enterpreneur & 10 & 25 \\
\hline House wives & 6 & 15 \\
\hline Farmer & 20 & 50 \\
\hline \multicolumn{3}{|l|}{ Smoking status } \\
\hline Non smokers & 8 & 20 \\
\hline Smokers & 32 & 80 \\
\hline
\end{tabular}

Based on the data on the clinical picture of the distribution of characteristics of lung adenocarcinoma patients in this study in Table 4.1, the mean age of lung adenocarcinoma patients was $57 \pm$ SD 11.71 years. The highest age group is $58-67$ years, as many as 16 people (40\%) and the least is the 18-27 year age group, only 1 person $(2.5 \%)$. The youngest patient was 18 years old, while the oldest was 74 years old. There were 34 male patients $(85 \%)$ compared to only 6 female patients $(15 \%)$.

The most patients with lung adenocarcinoma in this study were the Batak tribe, namely 17 people (42.5\%), followed by the Javanese as many as 10 people (25\%), the Mandailing tribe 7 people $(17.5 \%)$, the Karo tribe 3 people $(7.5 \%)$, there are 2 Malays (5\%), and the least is the Acehnese, which is only 1 person $(2.5 \%)$. Based on occupation, the distribution of samples in this study were mostly farmers with 20 patients $(50 \%)$, followed by 10 entrepreneurs $(25 \%)$, and housewives (IRT) $6(15 \%)$, and the most few are PNS/BUMN as many as 4 people $(10 \%)$. Smoking status of patients with lung adenocarcinoma in this study, with a history of smoking was 32 people $(80 \%)$ more than patients who did not smoke as many as 8 people $(20 \%)$. 
In this study, clinical data including the location, size and stage of the tumor were secondary data taken from medical records at the Haji Adam Malik General Hospital Medan. The frequency distribution of the characteristics of lung adenocarcinoma patients in this study can be seen in table 4.2.

Table 4.2. Frequency Distribution of Characteristics of Lung Adenocarcinoma Patients based on Location, Size and Tumor Stage Data

\begin{tabular}{lcc}
\hline & $\begin{array}{c}\text { Amount } \\
(\mathbf{n})\end{array}$ & $\begin{array}{c}\text { Percentage } \\
(\boldsymbol{\%})\end{array}$ \\
\hline Tumor location & & \\
Peripheral & 24 & 60 \\
Central & 16 & 40 \\
Tumor size & & \\
$\leq 2 \mathrm{~cm}$ & 12 & 30 \\
$>2-\leq 3 \mathrm{~cm}$ & 6 & 15 \\
$>3-\leq 5 \mathrm{~cm}$ & 11 & 27,5 \\
$>5-\leq 7 \mathrm{~cm}$ & 4 & 10 \\
$>7 \mathrm{~cm}$ & 7 & 17,5 \\
Tumor stage & & \\
III & 2 & 5 \\
IIIA & 1 & 2,5 \\
IIIB & 8 & 20 \\
IV & 3 & 7,5 \\
IVA & 21 & 52,5 \\
IVB & 5 & 12,5 \\
Total & 40 & 100 \\
\hline
\end{tabular}

The frequency distribution of lung adenocarcinoma patients based on tumor location in table 4.2 in this study was more located in the peripheral area as many as 24 cases $(60 \%)$ than those located in the center, which was 16 cases $(40 \%)$. The frequency distribution in this study based on tumor size (Table 4.2), the most were diameter $2 \mathrm{~cm}$ in 12 cases (30\%), followed by size $>3$ but 5 $\mathrm{cm}$ in 11 cases $(27.5 \%)$, size $>2$ but $3 \mathrm{~cm}$ as many as 6 cases $(15 \%)$, and those measuring $>7 \mathrm{~cm}$ in 7 cases $(17.5 \%)$, while the least are those measuring $>5$ but $7 \mathrm{~cm}$ in 4 cases $(10 \%)$.

The frequency distribution of lung adenocarcinoma patients based on clinical stage in this study (Table 4.2) was the most common stage IVA which was 21 cases $(52.5 \%)$, followed by stage IIIB as many as 8 cases (20\%), stage IVB 5 cases (12.5\%), stage IV as many as 3 cases (7.5\%) and stage III as many as 2 cases (5\%). The least clinical stage was stage IIIA in 1 case $(2.5 \%)$.

In this study, histopathological subtypes were categorized into 6 groups, namely, lepidic adenocarcinoma, acinar adenocarcinoma, papillary adenocarcinoma, papillary adenocarcinoma, micropapillary adenocarcinoma, solid adenocarcinoma, fetal adenocarcinoma and enteric adenocarcinoma which are presented in table 4.3. 
Table 4.3. Frequency Distribution of Lung Adenocarcinoma Patients based on Histopathological Variants

\begin{tabular}{lcc}
\hline \multicolumn{1}{c}{ Varian } & $\begin{array}{c}\text { Amount } \\
(\mathbf{n})\end{array}$ & $\begin{array}{c}\text { Percentage } \\
(\boldsymbol{\%})\end{array}$ \\
\hline Lepidic adenocarcinoma & 2 & 5 \\
& & \\
Acinar adenocarcinoma & 0 & 0 \\
Papillary adenocarcinoma & 8 & 20 \\
Micropapillary adenocarcinoma & 4 & 10 \\
Solid adenocarcinoma & 21 & 52,5 \\
Fetal adenocarcinoma & 4 & 10 \\
Enteric adenocarcinoma & 1 & 2,5 \\
Total & 40 & 100 \\
\hline
\end{tabular}

Based on the distribution of lung adenocarcinoma patients with histopathological subtypes, the most solid variants of adenocarcinoma were found in 21 cases $(52.5 \%)$, papillary adenocarcinoma variants in 8 cases $(20 \%)$, for micropalliary adenocarcinoma variants and fetal adenocarcinomas, 4 cases (10\%) were found. , the enteric adenocarcinoma variant was found in 1 case $(2.5 \%)$ while the acinar adenocarcinoma variant was not found.

The number of patients diagnosed histopathologically with the core biopsy method as lung adenocarcinoma at the Haji Adam Malik General Hospital Medan in 2017-2019 was 108 people. Of this total, only 40 patients were included in the study sample. Based on the number of cases of this lung adenocarcinoma.

The frequency distribution of lung adenocarcinoma patients in this study (Table 4.1) was most commonly found in the 58-67 year age group as many as 16 people (40\%) of the 40 samples with a mean age of 57 years \pm SD 11.7 years. The results of this study are in accordance with the research of Dana Hendrawan Putra et al. in 2016 in Surabaya which was found as many as 20 people (54\%) in the 41-60 year age group from 37 samples of lung adenocarcinoma patients, and the research of Supartono and Agus Suryanto at Dr. RSUP. Kariadi Semarang in 2012 as many as $65.8 \%$ in the age group 51-60 years, as well as research by Kyu et al in Korea in 2011 which proved the tendency of lung cancer in the age group above 65 years. This situation is caused by increasing age, the higher the risk for lung cancer, the occurrence of functional and molecular changes of the lungs with increasing age. These changes ultimately activate some of the cells that cause lung cancer. ${ }^{6}$

Changes in the architecture and function of the lungs. Along with age, the organs in the body will also age. So there have been some significant changes. In this elderly age, the lungs will also experience changes in function and architecture. One of them is the increasing space or air space. But on the other hand, the supporting tissue of the lungs will be reduced or weaker. In the end the air exchange will also be disrupted with a reduced surface as well. From this disruption of air exchange, residues will appear which increase the risk of lung cancer. ${ }^{6}$

Cilia change occurs. Still related to the first cause, the residue that collects in the lungs cannot be completely removed because of changes in the cilia. The slowing of cilia movement makes cleaning of debris and residue from the lungs incomplete. So that ultimately infection is easier to occur, with these ciliary changes, the risk for lung cancer will be higher. ${ }^{6}$

Immunology is not effective. In old age, the body's immune system will decrease. This causes disturbances in many vital organs. One of them is the lungs. This decreased immunity makes the body imperfect in fighting the bad cells that appear. ${ }^{6}$ 
Lung cancer is the leading cause of death in almost all of the world, especially in men. From year to year the number increases both in Japan, Europe, America and Indonesia. ${ }^{6}$ Cases of lung cancer are currently increasing in number and become one of the health problems in the world, including in Indonesia. In Indonesia, lung cancer is ranked 3rd or 4th among malignancies in hospitals. ${ }^{11}$ Lung cancer is generally found in middle age and thereafter. The ratio of men and women is $2: 1$ and the most histopathological subtype is adenocarcinoma at $54 \%{ }^{7}$

Based on the age distribution of the patients, the youngest age was 11 years old while the oldest was 74 years old with an average age of $57 \pm$ SD 11.71 years. Other studies say that the incidence of lung cancer is lowest at the age of under 40 years, but increases up to the age of 70 years. According to Lin et al. the median age at diagnosis was 56 years (34-78 years). Wu et al. in his research data obtained that the average age is 58.94 years (32-84 years). Azuma et al. also obtained data that the median age of all patients was 66 years (39-82 years). ${ }^{8}$

Some of the reasons that can explain this phenomenon are because few patients can be diagnosed early, decreased immunity, decreased repair of mutated DNA and exposure or inhalation of substances that cause It is carcinogenic and accumulates and begins to show its effects when the patient is over 40 years of age.

Based on the sex distribution of the patients, there were more men suffering from lung adenocarcinoma, as many as 32 people (85\%) and 8 women (15\%). The results of a hospital-based study from 100 hospitals in Jakarta showed that lung cancer was the most common case in men and number 4 in women, and was the leading cause of death in both men and women. Dharmais Hospital cancer registration data for 2003-2007 showed that trachea, bronchus and lung cancer was the second most common malignancy in men (13.4\%) after nasopharyngeal cancer (13.63\%) and was the most common cause of cancer death in men (28). ,94\%). Based on WHO data, lung cancer is the most common type of cancer in men in Indonesia, and the fifth most common for all types of cancer in women.

Based on the National Guidelines for Medical Treatment (PNPK) for lung cancer, it was found that lung cancer is also the most common cause of death in men and the second most common in women. According to research by Azuma et al. Of the 164 patients, 91 were male $(55 \%){ }^{9}$ According to research by Janzic et al. it was found that the most cases were men, namely 34 people (63\%) and women as many as 20 people (37\%). Research by Lin et al. of 118/170 $(69.4 \%)$ patients were male. This is different from the research of Wu et al. that the majority were women, namely 80 people while men were 53 people. In this study, the highest number was suffered by men compared to women, similar to several previous studies, but indeed different from the research conducted by $\mathrm{Wu}$ et al. Lung cancer is more common in men than women with the ratio between men and women being 1.5:1. More than $90 \%$ of lung cancer patients are over the age of 40, although there have been reports of lung cancer cases affecting young adults. In a study conducted by Betty S. Hernowo, lung adenocarcinoma was $25 \%$ in men and $42 \%$ in women. ${ }^{10}$

Research conducted in the United State by Rao stated that men are more often affected by lung cancer which is caused by many factors, one of which is the influence of smoking. Several journals state that lung adenocarcinoma in smoking patients occurs mostly in men but few in women, while the majority of nonsmokers are women. The content in cigarettes that can cause risk factors for adenocarcinoma in women is less than in men. However, in the literature, the idea of "greater susceptibility" or "better susceptibility" is found among women.

The high ratio of men to women according to Zang and Wynder is due to the fact that men have a habit of smoking with a greater number and deeper suction and a more frequent frequency. This is evidenced by smoking history data, which is 32 cases $(80 \%)$ while patients were not smokers 8 cases (20\%). Of the 8 patients who were not smokers, 6 of them were female patients and only 2 were male patients. This result contrasts with another study which stated that $85 \%$ of lung cancer patients in women were female smokers. ${ }^{12}$ In Indonesia, the prevalence of female 
smokers is low, in contrast to western countries where the prevalence of female smokers increases with the progress of time and urbanization. Factors that cause lung cancer in men who smoke or do not smoke include genetic susceptibility. Although none of the female patients were recorded as having a history of smoking, female patients were prone to being passive smokers but such data were not recorded in the medical records. In addition, female patients have differences in the enzyme cytochrome P-450. ${ }^{13}$ Hormonal factors that play a role in the emergence of lung cancer are estrogen which can trigger carcinogenesis by activating cell proliferation directly in lung fibroblasts or through metabolic activation causing oxidative damage to the lungs, caused by changes in smoking habits and the increased incidence of lung cancer in non-smokers. ${ }^{14}$

Based on the ethnic distribution of the sufferers, it is known that the Batak tribe suffers more from lung adenocarcinoma, as many as 17 people $(42.5 \%)$. This does not show the relationship between ethnicity and the incidence of lung cancer, but only shows that lung cancer patients who seek treatment at H. Adam Malik Hospital Medan are mostly Bataknese. This is in line with the results of Melindawati's research with a case series design, the highest proportion of ethnic groups is Batak 58.5\%, followed by Javanese 23.0\%, Aceh 11.5\%, Minang 3.5\%, Malay 3.0\% and Nias 0 , $5 \% .^{15}$

Based on the distribution of the patient's occupation, it is known that the farmers suffer from lung adenocarcinoma more than 20 people (50\%). Another study by Nallapen at Adam Malik General Hospital, found that patients were dominated by entrepreneurs as many as 29 cases $(35.8 \%)$ and research by Bhaskarapillai et al. in India, namely manual labor as many as 85 cases (30.25\%). In M. Arga's research in 2017 at Wahidim Sudirohusodo Hospital, Makassar, it was dominated by entrepreneurs with a total of 9 cases $(20.9 \%) .{ }^{11}$

Various risk factors have been shown to be associated with the incidence of lung cancer, including prolonged exposure to industrial exhaust gases, chemicals such as arsenic, asbestos and motor vehicle exhaust gases containing carcinogens, especially the most prominent carcinogen benzopyrene. Factors such as air pollution from cooking smoke and household heating have a greater role in the etiology of lung cancer in nonsmokers, especially among women.

Based on the distribution of smoking status of patients, it is known that smoking suffers more from lung adenocarcinoma, as many as 32 people (80\%). Smoking was associated with a $70 \%$ increase in the male-specific mortality rate and a lower increase in the female mortality rate. The magnitude of the effects of smoking far exceeds all other factors that cause lung cancer. The risk of lung cancer increases with duration of smoking and the number of cigarettes smoked per day. The report estimates that the average male smoker has a 9- to 10-fold risk of lung cancer, while heavy smokers have at least a 20-fold risk. In a case-control study in the UK, Doll and Hill described an association between lung cancer and smoking and the effect of the amount of cigarette use on the development of lung cancer. ${ }^{16}$

In the study of Koh et al. there were 137 cases of patients (64.3\%) who smoked and only 96 cases $(35.7 \%)$ who did not smoke. Schuurbiers et al. In his research, 96 samples of men smoked and 3 samples of non-smokers. ${ }^{17}$ According to research conducted by Johana, most of the lung adenocarcinoma patients were women and nonsmokers, while men were smokers. Although lung adenocarcinoma is common in patients who are not smokers, the incidence rate in patients with smokers is also quite high. According to Johana, the number of cases of lung adenocarcinoma in patients who are not smokers is related to the subtype of lung adenocarcinoma itself. In the study conducted by Karina Fauziah, Ris Kristiana, Lukman Tobing in 2019 out of 20 patients 15 (75\%) with non-smoker status were diagnosed lung adenocarcinoma. In the study of Fanny Kamarudy Lay, Endah Zuraidah, Yayi Dwina Billianti also concluded that lung adenocarcinoma cases were more common in non-smokers. ${ }^{18}$

Cigarette smoke induces extensive histologic changes in the bronchial epithelium in smokers' lungs and premalignant lesions are widespread and multifocal throughout the respiratory 
epithelium. This phenomenon triggers the occurrence of cancer, which later becomes evidence in various epithelial cell malignancies including lung cancer. Some degree of inflammation and damage is almost always seen in the central and peripheral airways of smokers and it is this that precedes the development of lung cancer. ${ }^{19}$

This is related to the phenomenon that the process of cancer is preceded by genetic changes or repeated mutations until one day these changes are able to cause uncontrolled cell proliferation. Meanwhile, lung cancer originates from the airway epithelium after undergoing morphological changes. Starting from normal epithelial cells, hyperplasia, metaplasia, dysplasia, carcinoma in situ, invasive cancer and ending as metastatic cancer. When experiencing this process of tumor genesis, genetic changes are repeated until one day a malignancy phenotype is formed. Genetic changes that lead to the process of malignancy can occur if there is a disturbance in 4 groups of normal growth regulating genes, namely: proto-oncogenes (genes that trigger growth), cancer suppressor genes (growth inhibiting genes/anticogenes), apoptosis (genes that regulate programmed cell death) and genes. DNA repair. Get to know more about the molecular biology of cancer cells. ${ }^{20}$

The frequency of smoking based on a survey of 87 countries conducted by WHO in $85 \%$ of the world's population shows that $47 \%$ of men and $12 \%$ of women are aged 15 years and over. The survey was conducted 20 years ago and a more recent report estimates that the number of male smokers decreased but on the contrary increased in women. This figure is important when it is associated with the estimated number of new lung cancer cases. Jemal et al. reported on the estimated new cases and deaths from lung cancer per year and the correlation between the number of smokers and lung cancer. ${ }^{21}$

Based on the previous description, lung cancer is associated with smokers, in Indonesia the number of smokers is in the fifth highest rank. Therefore, this paper is very meaningful for reducing lung cancer morbidity. One of the primary prevention of lung cancer is health promotion in the form of counseling or socialization. In addition, lung cancer is still lacking in terms of health promotion. With this study, the problem of lung cancer can be controlled properly.

In table 4.2, it is known that in peripheral locations suffer from lung adenocarcinoma more, as many as 24 people (60\%). Lung adenocarcinoma usually occurs more in the periphery, followed by a central scar. In general, adenocarcinoma grows slowly and forms a smaller mass than the other types, but adenocarcinoma has a tendency to metastasize extensively at an early stage. According to the study of Russel et al. showed that all subtypes of invasive lung adenocarcinoma had the most common location in the periphery of the lung, while $33 \%$ of solid, $25 \%$ of micropapillary and $20 \%$ of acinar were centrally located. In general, adenocarcinoma grows slowly and forms a smaller mass than the other types, but adenocarcinoma has a tendency to metastasize extensively in the early stages. $^{22}$

Tumor size in this study was obtained from secondary data in the medical records of Haji Adam Malik Hospital Medan, which can be seen in table 4.2. It can be concluded that tumor size 2 $\mathrm{cm}$ is more likely to suffer from lung adenocarcinoma, as many as 12 people (30\%). Where the most locations in the peripheral area. Tumor size $>5-\leq 7$ data obtained at least 4 people $(10 \%)$ with the most locations in the peripheral area. While the tumor size $>7$ obtained as many as 7 people $(17.5 \%)$ with the most central areas. Theoretically there is no relationship between tumor size with this study. Table 4.2 also concludes that more lung adenocarcinoma patients were diagnosed at stage IVA, as many as 21 people (52.5\%). These results are consistent with a study conducted by Ellis and Vandermeer who found results for non-small cell lung carcinoma in stage IV as many as 15 cases $(29 \%)$ and stage IIB in 13 cases $(25 \%)$. However, for the case of small cell lung carcinoma Ellis and Vandermeer got 6 cases $(11 \%)$ with extensive stage and 6 cases (11\%). According to research by Azuma et al. stage I, II, III were 67 (40.8\%), 46 (28\%), and 51 people (31\%). Lin et al. reported stages I, II, and III were 50 (29.4\%), 43 (25.3\%), and 77 people (45.3\%), where in this study most cases were at an advanced stage (III \& IV). namely as many as 21 people $(63.4 \%){ }^{23}$ 
Based on the TNM stage, the most were stage IIIB 51 people (62.2\%), followed by stage IIIA 16 people (19.5\%) and stage IV as many as 15 people $(18.3 \%) .{ }^{24}$ In the study of Taufik et al. (2006) which states that stage III is the most common case of lung cancer. ${ }^{25}$

The main reasons for delays in treatment of lung cancer patients in developing countries are low awareness of health, many patients with early cases who choose to seek treatment in traditional medicine and delays in referring patients to specialized health centers. The low survival rate of lung cancer patients is because most lung cancer patients in Indonesia seek treatment after a severe illness or at a very advanced stage so that the success rate of treatment given is much smaller. ${ }^{26}$

This shows that the patient's lack of awareness comes for treatment or self-examination if there are mild complaints. Most patients who come for treatment and are treated are diagnosed with advanced stage lung cancer. Most of the patients treated were referrals from local hospitals and health centers, the reason being that there were no specialist doctors and supporting tools to diagnose lung cancer. Lack of knowledge and cost is a problem for most lung cancer patients. If you have entered an advanced stage, usually even these cancer cells can continue metastasize. Lung cancer is a lung disease that requires fast and targeted treatment and action. ${ }^{27}$

In table 4.4, it is known that the solid variant is more common in lung adenocarcinoma patients, as many as 21 people (52.5\%). According to the research of Wu et al. 16 cases of lepidic, 65 acinar cases, 8 cases of mucinus, 18 solid cases, 19 papillary cases, and 7 micropapillary cases, ${ }^{28}$ However, this is different from the study of Igarashi et al. where the most is the papillary subtype ${ }^{429}$ While in this study the tissue samples came from biopsy preparations, where the tissue obtained was very minimal so that the adenocarcinoma variant was not clearly displayed.

\section{Conclusion}

Based on the specific objectives of the profile study of lung adenocarcinoma patients on core biopsy examination at the Haji Adam Malik General Hospital Medan in 2017-2019, it can be concluded:

1. The total number of patients with lung adenocarcinoma was 108 people, but the number of patients who could be used as samples in this study was only 40 people. The mean age of the patients was 57 years with a minimum of 11 years, a maximum of 74 years and a standard deviation of 11.71 years. Most lung adenocarcinoma patients were aged 57-68 years (50\%). As many as $80 \%$ of men suffer from lung adenocarcinoma. For work, more farmers suffer from lung adenocarcinoma, as many as 20 people $(50 \%)$. The Batak tribe suffers more from lung adenocarcinoma, as many as 17 people $(42.5 \%)$. Smoking status suffered from lung adenocarcinoma more, as many as 32 people $(80 \%)$.

2. From the distribution of tumor locations, peripherally more suffer from lung adenocarcinoma, as many as 25 people (62.5\%). That the tumor size $2 \mathrm{~cm}$ more suffered from lung adenocarcinoma, as many as 12 people (30\%). For stage IVA, there were more lung adenocarcinomas, as many as 21 people $(52.5 \%)$.

3. From histopathology, it was found that the solid variant had more lung adenocarcinoma, as many as 21 people $(52.5 \%)$.

\section{Acknowledgements}

We would acknowledge to all staf and resident of Anatomical Pathology Department of Universitas Sumatera Utara and H. Adam Malik hospital, Medan, Indonesia for their help and cooperation. 


\section{References}

1. Kementrian Kesehatan Republik Indonesia. Pedoman Nasional Pelayanan Kedokteran. Kanker Paru, 2017

2. Nguyen LN, Maurer B, Sulaiman YA, Morsbach F, Distler O, Frauenfelder et al. The impact of slice-reduced computed tomography on histogram-based dwnsitometry assessment of lung fibrosis in patients with systemic sclerosis. J Thorac Dis, 2018, 10(4): 2142-2152.

3. Jack A, Waun Ki Hong, and James D. Cox. Lung Cancer.Ed.3.2008.

4. KP Andhika, NS Noni, T Hendra, Peran Biopsi Jarum Inti Transtoraks Pada Diagnostik Nodule Pusat dan Perifer/ Massa Menggunakan CT Scan Dada dan Panduan USG Dada, 2019.

5. Gardelli G, Feletti F, Nanni A, Mughetti M, Piraccini A, Zompatori M et al. Chest Ultrasonography in the ICU. Respiratory Care, 2012, 57 (5) 773-781.

6. Kanker paru merupakan salah satu jenis penyakit kanker dengan resiko kematian paling besar, Dr. Abidinsyah Siregar,DHSM,MBA,MKes, Oktober 6, 2018

7. Janto, dkk, 1995 (Janto Poernomo Hadi, Sutjipto Dwijo, Slamet Harijadi dan Soegeng Sukamto, Kanker paru pada seorang anak perempuan, Jurnal Paru, vol 15 no 1, Januari 1995, p.43-44.

8. Perhimpunan Dokter Paru Indonesia. Kanker Paru (Kanker Paru Jenis Karsinoma Bukan Sel Kecil). Pedoman Diagnosis \& Penatalaksanaan di Indonesia. Jakarta: PT. Metro Offset Printing ; 2011: p.2-10

9. Igarashi $\mathrm{T}$, Teramoto $\mathrm{K}$, Ishida $\mathrm{M}$, et al. Scoring of PD-L1 expression intensity on pulmonary adenocarcinomas and the correlations with clinicopathological factors. ESMO Open 2016;1:e000083. Doi: 10.1136/ esmoopen-2016-000083.

10. Bethy S. Hernowo, Karsinoma paru, Integrated Respiratory Care 2012

11. Cruz C S, Tanoue LT, Matthay R A. Lung Cancer: Epidemiology, Etiology and Prevention Pulmonary and Critical Care Medicine Section, Department of Internal Medicine, Yale University School of Medicine, 300 Cedar Street, TAC S441-C, New Haven, CT 06519, USA. 2011.

12. Behera D, Balamugesh T. Lung cancer in India. The Indian journal of chest diseases \& allied sciences. 2004 Oct-Dec;46(4):269-81. PubMed PMID: 15515828.

13. Saragih, H. M. Profil Penderita Kanker Paru yang Dirawat di Rindu A3 (RA3) RSUP Haji Adam Malik Medan Tahun 2007-2010 [Internet]. 2012 [cited 16 dec 14] Available:http://repository.usu.ac.id/bitstream/123456789/33388/3/Chapter\%20II.pdf

14. Thun MJ, Henley SJ, Burns D, Jemal A, Shanks TG, Calle EE. Lung cancer death rates in lifelong nonsmokers. Journal of the National Cancer Institute. 2006 May 17;98(10):691-9. PubMed PMID: 16705123.

15. Muhammad Arga Putra, Karakteristik penderita kaknker paru di Rumah Sakit Wahidim Sudirohusodo Makasar periode Januari-Desember 2016, 2017

16. Russell PA, Barnett SA, Walklewlcz M, et al. Correlation of mutation status and survival with predominant histologic subtype according to the new IASLC/ATS/ERS lung adenocarcinoma classification in stage III (N2) patients. J Thorac Oncol.2013;8:461-8

17. Makinen, Johanna. Lung Adenocarcinoma. Histopathological Features And Their Association With Patient Outcome; 2017.p.23-52.

18. Fanny Kamarudy Lay, Endah Zuraidah, Yayi Dwina Billianti, Gambaran Klinik, Histopatologik, dan Molekuler Fusi Gen RET (Rearranged During Transfection) pada Adenocarcinoma Paru, 2019 
19. Shigematsu H, Lin L, Takahashi T, Nomura M, Suzuki M, Wistuba II, et al. Clinical and Biological Features Associated With Epidermal Growth Factor Receptor Gene Mutations in Lung Cancers. Journal of the National Cancer Institute. 2005 ; 97(5):339-46

20. Ahmad Hudoyo, Mengenal lebih dekat biologi molekuler sel kanker. J Respir Indo, vol 23, no : 2 : 2003, p 99-104.)

21. Jemal A, 2006; Taufik, 2006 Jemal A, Siegel R, Murray T, Cancer statistic. Cancer J Clin, 2006; 56: p.106-130.)

22. Peters S. Immunotherapy for lung cancer. Annals of Oncology Conference: 13th Annual Meeting of the Japanese Society of Medical Oncology Sapporo Japan Conference Start: 20150716 Conference End: 20150718 Conference Publication: (varpagings)2015. p. vii7

23. Funal K, Yokose T, Ishii G, et al. Clinicopathologic characteristics of peripheral squamous cell carcinoma of the lung. Am J Surg Pathol. 2003. 27:978-84.

24. Supartono, Agus Suryanto, Faktor-faktor yang mempengaruhi ketahanan hidup satu tahun penderita kanker paru stadium lanjut di RSUP Dr. Kariadi Semarang, Med Hosp; Mei 2012.

25. Jusuf A. Pengobatan kanker paru menurut konsesus Bali 20 01. Dalam : MargonoBP, Widjaja A, Amin M,ed.Pertemuan ilmiah paru milenium 2002.Surabaya:PDPI 2002 S- 2

26. Wu S, Shi X, Sun J, et al. The significance of programmed cell death ligand 1 expression in resected lung adenocarcinoma. Oncotarget, 2017, Vol. 8, (No. 10), pp: 16421-16429

27. Lee CK, Brown C, Gralla RJ, Hirsh V, Thongprasert S, Tsai CM, et al. Impact of EGFR Inhibitor in Non-Small Cell Lung Cancer on Progression-Free and Overall Survival : A MetaAnalysis. Journal of the National Cancer Institute. 2013 ; 105: 595- 605.

28. Oktaviyanti, IK. Mutasi EGFR pada Pemeriksaan Berkala Kedokteran, Vol.11, No.2, Sep 2015: 213-219

29. Igarashi T, Teramoto K, Ishida M, et al. Scoring of PD-L1 expression intensity on pulmonary adenocarcinomas and the correlations with clinicopathological factors. ESMO Open 2016;1:e000083. Doi: 10.1136/ esmoopen-2016-000083. 